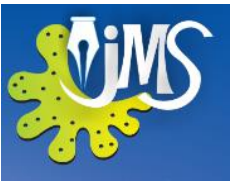

\title{
Assessment of Heavy Metal in Urbanized Tropical River in Ibadan, Nigeria
}

Iroye K.A.* , and Igbozurike J.C.

Department of Geography and Environmental Management, University of Ilorin, Nigeria

\begin{abstract}
Contamination by heavy metals in river water is a global problem especially in developing countries like Nigeria. Ten heavy metals were investigated in River Ona located in Ibadan, a state capital in Nigeria. The river which stretches over more than $30 \mathrm{~km}$ length drains through different land uses in the city. Laboratory analysis conducted on ten water samples collected at $1 \mathrm{~km}$ equidistance position reveals that concentration levels of six (Lead, Cobalt, Copper, Zinc, Manganese and Iron) out of the ten heavy metal investigated in the study conform to the World Health Organization (2011) recommendation for human consumption while the remaining for elements (Cadmium, Chromium, Nickel and Arsenic) were above the WHO (2011) recommended levels. The mere presence of heavy metals in concentration near those limits considered safe for human consumption should be a matter of concern especially for residents who use the river water for domestic activities and those who consume fish from the river. A number of recommendations were subsequently put forward as a way of quality management of the river water.
\end{abstract}

KEYWORDS: Heavy Metals, Contamination, Pollution, Urbanization, Environment 


\section{INTRODUCTION}

Water is one of the most important resources without which no existence is possible. Though the hydrosphere is estimated to contain about 1.36 billion Km3of fresh water, 99.9 percent of this is locked up in seas and oceans with only 0.3 percent available for the use of man through sources such as rivers, streams, springs, groundwater and aquifers (Wilson, 1978). Apart from water being required by man, the resource is also of great demand in the maintenance of ecological balance. However, the world is currently experiencing scarcity of fresh water supply, most especially in the developing countries. According to UNICEF (2016), women across the world spend 200 million hours a day to search and collect water. Because scarcity of water is increasing, there is thus the need to plan, monitor and manage the resources especially for the purpose of sustainable development (Iroye, 2017).

Among the oldest water sources in the world are rivers (Higler, 2012). Rivers and their catchments constitute an important part of the natural environment and play an integral part in the sustainability and livelihood of communities; and due to the universal usefulness of water, most communities are often found along riverbanks. Their status, therefore, affects the health and well-being of humans, animals and plants that depend on them. However, number of factors determine both the quantity and quality of river water. Among such factors include natural processes of precipitation, weathering and erosion and anthropogenic activities such as urban development, industrialization, transportation and agricultural activities.

One of the factors of quality impairment of surface water is pollution by heavy metals. Heavy metal refers to any metallic chemical element that has a relatively high density and is toxic and poisonous even at low concentrations. According to Tam and Wong (2000), heavy metals are one of the most serious pollutants in man's natural environment due to their toxicity, persistence and bioaccumulation problems. As a result of human activities, the rate and degree of heavy metal pollution in natural water bodies has been on the increase. According to Wangboje and Ekundayo (2013), the presence of heavy metals in water bodies is leading to a variety of negative impacts with the consequent effect on the ecosystem.

In surface water such as rivers and other natural aquatic ecosystems, heavy metals occur naturally in low concentrations, normally at the nanogram to microgram per liter level. In recent times, however, it's occurrence have become a problem of increasing concern (Islam et al., 2015). This situation according to Biney et. al. (1991) and Martin et al., (2015) has arisen as a result of rapid growth of population, increased urbanization, expansion of industrial activities, exploration and exploitation of natural resources, extension of irrigation and other modern agricultural practices, as well as nonenforcement of environmental regulations. The major routes of heavy metal uptake by man are through food, drinking water and air. For example, aquatic animals, most especially fish which are consumed by man, is a source of mercury (Hg) contamination.

As trace elements, some heavy metals such as copper and zinc are essential to maintaining the metabolism of the human body; however, at higher concentrations, they can lead to poisoning. Heavy metals linked most often to human poisoning are lead $(\mathrm{Pb})$, mercury $(\mathrm{Hg})$, arsenic (As) and cadmium (Cd). Others such as copper $(\mathrm{Cu})$, zinc $(\mathrm{Zn})$ and chromium $(\mathrm{Cr})$ are 
actually required by the body in small amounts, but can also be toxic in higher amount (Biney, et. al., 1991).

Ayoade (1988) and Adebola (2001), observed that water resource problems worldwide are generally of three main types; these are problems of too little water, too much water and polluted water. In the case of River Ona, the main focus in this investigation, the problem is polluted water which comes in form of heavy metals and other impurities in the river water. This pollution problem may not be unconnected with the numerous socio-economic activities taking place within the riparian environment of the river. Much of the wastes generated within the drainage basin are usually discharged into the river untreated. These wastes apart from adversely affecting the normal hydrochemistry of the river also result in debris pile up on the river bed and decrease channel capacity at various points, thus inducing flood.

While the resultant effects of polluted water on public health and environment are enormous, pollution of rivers by heavy metals are especially dangerous on aquatic organisms and man. Their presence in water causes imbalance in the ecological distribution of both fauna and flora organisms. Dadzie (2012) observed that the consumption of arsenic leads to skin cancer and cardiovascular diseases while consumption of lead and mercury leads to breakdown of the central nervous system as well as neurological disorder.

Efficient and effective water quality management is a prerequisite for reducing pollution in water. It is germane for the protection of the integrity of the ecosystem. Such a task, however, begins with monitoring of water bodies as currently being done in this investigation. According to Milicevic (2013) monitoring as defined by the International Organization for Standardization (ISO) is the program process of sampling, measurement and subsequent recording or signaling or both, of various water quality characteristics, often with the aim of assessing conformity. This task is being carried out in this study through the assessment of concentration levels of heavy metals, examination of the spatial variability in concentration levels of the heavy metals and investigation of the nature of inter-relationships among the heavy metals.

\section{The Study Area}

Ibadan, Oyo State capital located in the south-western part of Nigeria (Fig 1) is the study area in this investigation. Ibadan is located between longitudes $3^{\circ} 55^{\prime} \mathrm{E}$ and $3^{\circ} 91^{\prime} \mathrm{E}$ and between latitudes $7^{\circ} 23^{\prime} \mathrm{N}$ and $7^{\circ} 39^{\prime} \mathrm{N}$. The city is located approximately $145 \mathrm{~km}$ north of Lagos. It lies completely within the tropical forest zone. Ibadan is regarded as the largest indigenous city in tropical Africa with a population of about 2,550,593 (NPC, 2006). In terms of physical expansion and land coverage, this pre-colonial urban center has expanded very fast sprawling daily into the hinterland. Fabiyi (2006) noted that developed land in Ibadan increased from only 100 ha in 1830 to $214 \mathrm{~km} 2$ in 1988 . Ibadan currently covers a landmass of $400 \mathrm{~km} 2$ (Egbinola, et al., 2013). 


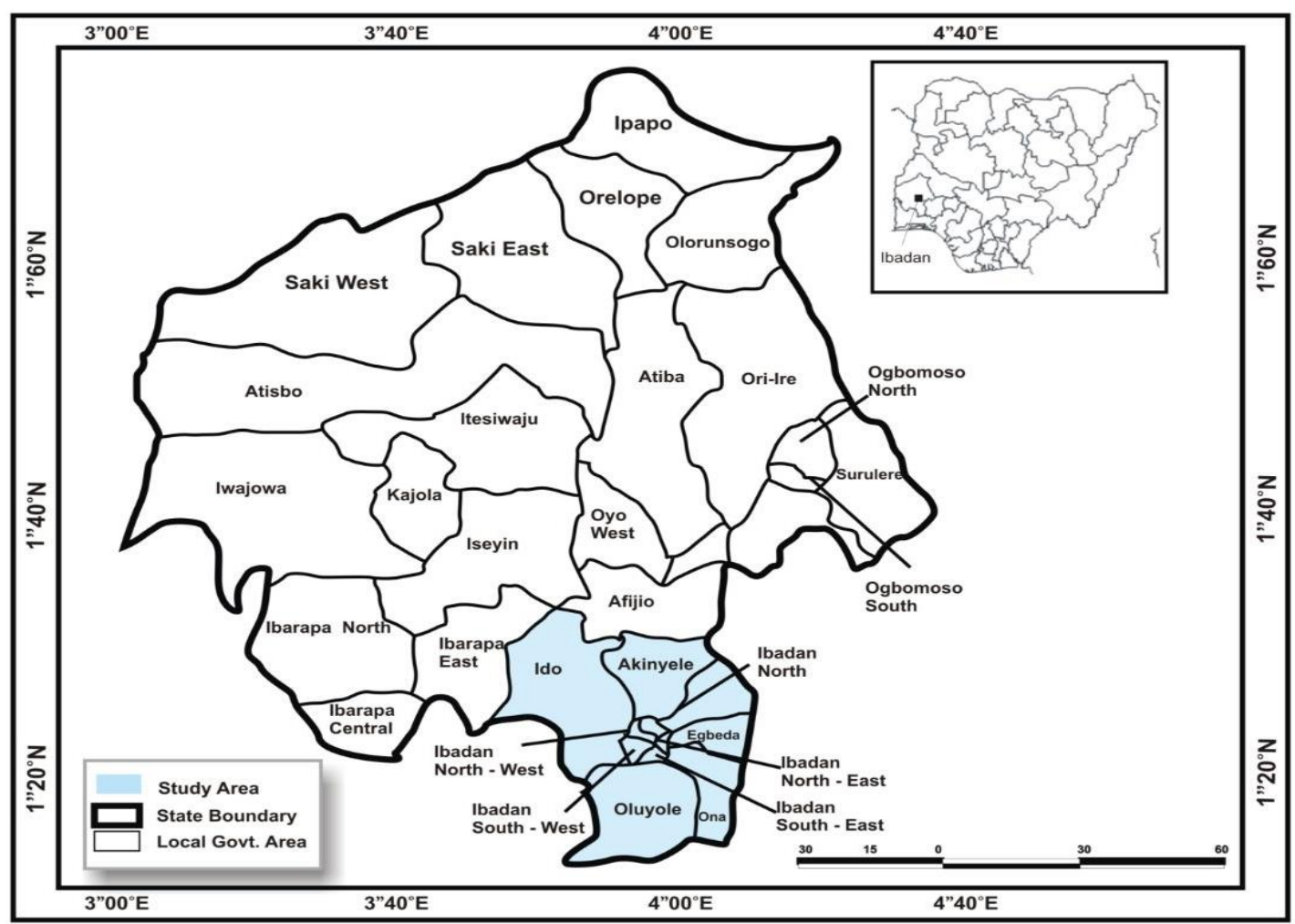

Figure 1 Map of Oyo State Showing Ibadan with Nigeria as Inset.

Source: Ministry of Lands and Housing, Ibadan, 2011.

The climate of Ibadan is influenced by the movement of the inter-tropical convergence zone (the ITCZ), a quasistationary boundary zone which separates the sub-tropical continental air mass over the Sahara and the equatorial maritime air mass over the Atlantic Ocean. The former air mass is characterized by the dry northeasterly winds known as Harmattan, the latter by the rain-bearing southwesterly winds from the Gulf of Guinea. Ibadan has an annual rainfall of about 1,306mm (Oke, et al., 2013). Rainy season in the region begins in early March and ends around the month of November while the dry season is experienced between the months of November and February. The change of the rainy season to the dry season in the area is rather abrupt while the onset of rains after the dry season is gradual. The month of February is the hottest when the temperature can reach as high as 34.60c.

Vegetation around Ibadan comprises of trees, herbs, shrubs, grasses and palms, most of which are evergreen. However, the impact of man has greatly been felt negatively on the vegetation. This is through various activities such as lumbering, construction and agricultural activities. Examples of tree species in the region include Bamboosa Aridinarifolia, Azadhirachta In dica, Mangifera Indica, Citrus Spp, Musa Paradisicum, while Axonopus Fissifolius, Heteropogon Canorous, and Pennistrum Purpureum are few examples of grass species.

Geologically, Ibadan is underlain by basement complex rocks which are 
mainly metamorphic rocks of Precambrian age with granite, quartzite and migmatite as the major types. The minor rock types include pegmatite, aplite and diorite. The city is dominated by three main landform units of plains, hills and rivers. The hills are the most striking features though they constitute less than 10 percent of the total surface area. This relief can generally be described as undulating with height ranging between 185 and 230 meters above sea level. Ibadan is drained by a network of rivers which exhibits a dendritic drainage pattern. Four important rivers in the city are Rivers Ogunpa, Ona, Kudeti and Ogbere.

River Ona which is the case study in this investigation flows in a north-south direction of the city from its source at IITA through Eleyele where it is dammed. It thereafter flows through Oluyole Estate to Odo Ona Elewe and eventually empties its water into the Lagos Lagoon. The river covers a length of over $30 \mathrm{~km}$ and it has a catchment area of $81 \mathrm{~km} 2$. River Ona, from its source to its mouth is crossed by three (3) dams. The first dam is located in IITA, the second is located in University of Ibadan while the third is the Eleyele dam found in the north where the Alapata stream joins the river (Alayande, et. al., 2012). River Ona thus serves as a dependable source of water for agricultural, industrial and domestic uses in the city.

\section{METHODOLOGY}

Water samples were collected from ten sampling points located at $100 \mathrm{~m}$ equidistance positions along the study river in the downstream segment beginning at a kilometer distance away from Eleyele Dam (Fig 2). The water samples were collected using sterilized $75 \mathrm{cl}$ plastic bottles. At the point of collection, the plastic bottles were rinsed twice with the same water to be collected. After the collection, each water sample was labeled with date and collection station. The collected water samples were later transported to the laboratory under preserved storage using cooler filled with ice cubes. This was to ensure that the characteristics to be analyzed are not changed between the time of collection and analysis.

The concentration levels of these heavy metals were analyzed in University of Ibadan Agronomy Laboratory using Atomic Absorption Spectrophotometer (AAS) method. This technique which is generally used in analyzing metals in water involves atomization of samples by thermal sources and the absorption of a specific wavelength by the atomic source as it is excited. The radiation used is a hollow cathode lamp containing, as its cathode, the same element under analysis. Greaney (2005) has earlier used the method to a great level of success. The instrument for the measurement was set up at wavelengths specific to each element to be analyzed based on APHA (2005).

Before determining the concentration of heavy metals through Atomic Absorption Spectrometer (AAS) method, the water samples were digested by measuring $20 \mathrm{ml}$ of each water sample into $50 \mathrm{ml}$ of an acid mixture of Nitric and Per chloric acid. The beaker content was placed on a heating mantle at $105^{\circ} \mathrm{C}$ for thirty minutes under a fume cupboard. The digest was allowed to cool and thereafter read on an Atomic Absorption Spectrometer. The results of the laboratory were subsequently subjected to descriptive statistical analysis. In all, concentration levels of ten heavy metals were examined; these heavy metals include zinc, lead, copper, cadmium, chromium, arsenic, nickel, cobalt, manganese and Iron. 


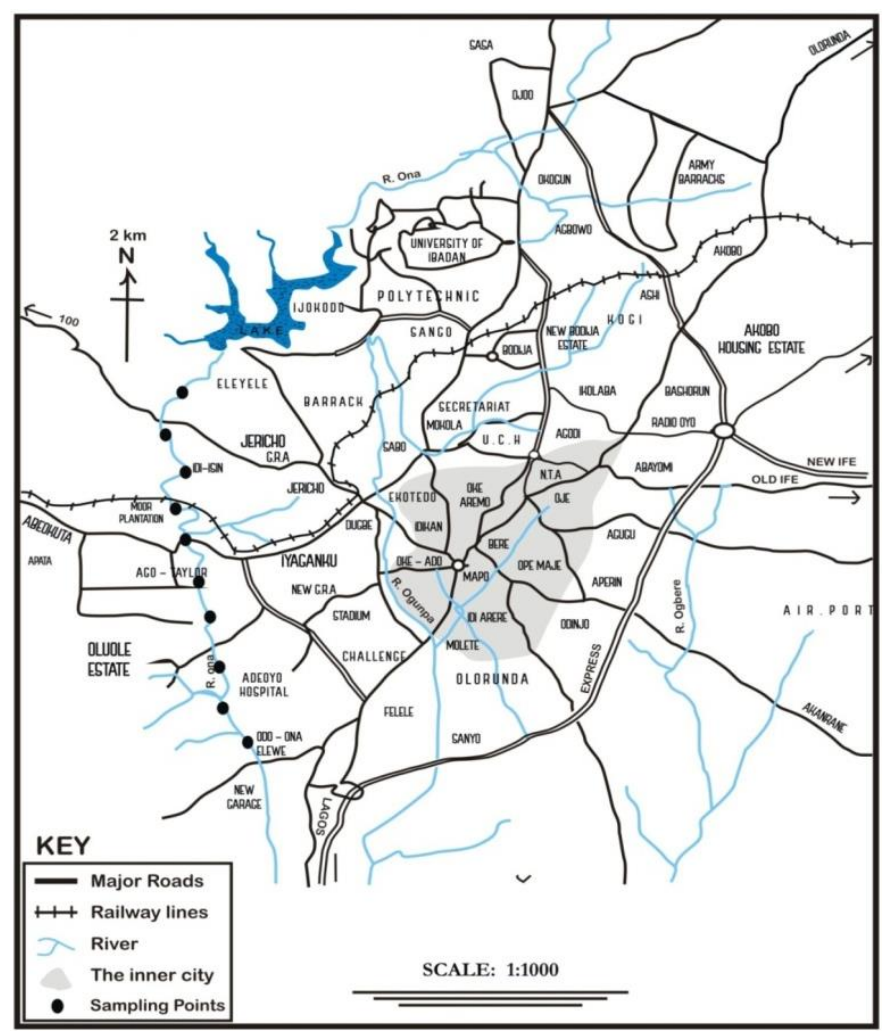

Figure 3.1: Street Map of Ibadan Showing the Sampling Locations Source: Fourchard (2003)

\section{RESULTS AND DISCUSSION}

Concentration of Heavy Metal in the Studied River

Table 1 presents the result of the laboratory analysis on heavy metals in water samples collected from River Ona

Table1: Heavy Metal Concentration in the Study Area

\begin{tabular}{|c|c|c|c|c|c|c|c|c|c|c|c|}
\hline $\begin{array}{l}\text { Pampling } \\
\text { Points }\end{array}$ & & $\begin{array}{c}\mathrm{Pb} \\
(\mathrm{mg} / \mathrm{l})\end{array}$ & $\begin{array}{c}\mathrm{Cd} \\
(\mathrm{mg} / \mathrm{l})\end{array}$ & $\begin{array}{c}\mathrm{Cr} \\
(\mathrm{mg} / \mathrm{l})\end{array}$ & $\begin{array}{c}\text { Co } \\
(\mathrm{mg} / \mathrm{l})\end{array}$ & $\begin{array}{c}\mathrm{Cu} \\
(\mathrm{mg} / \mathrm{l})\end{array}$ & $\begin{array}{c}\mathrm{Ni} \\
(\mathrm{mg} / \mathrm{l})\end{array}$ & $\begin{array}{l}\mathrm{Zn} \\
\mathrm{g} / \mathrm{I})\end{array}$ & $\begin{array}{c}\mathrm{Mn} \\
(\mathrm{mg} / \mathrm{l})\end{array}$ & $\begin{array}{c}\mathrm{Fe} \\
(\mathrm{mg} / \mathrm{l})\end{array}$ & $\begin{array}{l}\text { As } \\
(\mathrm{mg} / \mathrm{l})\end{array}$ \\
\hline Eleyele (1) & \multirow{2}{*}{ 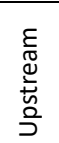 } & 0.04 & 0.00 & 0.02 & 0.02 & 0.001 & 0.040 & 0.037 & 1.33 & 3.22 & 0.08 \\
\hline Nihort (2) & & 0.05 & 0.01 & 0.02 & 0.01 & 0.001 & 0.030 & 0.000 & 1.95 & 2.46 & 0.08 \\
\hline
\end{tabular}




\begin{tabular}{|c|c|c|c|c|c|c|c|c|c|c|c|}
\hline Idi Ishin (3) & & 0.03 & 0.01 & 0.03 & 0.03 & 0.000 & 0.020 & 0.000 & 0.38 & 2.43 & 0.04 \\
\hline Moor plantation (4) & & 0.04 & 0.02 & 0.04 & 0.02 & 0.001 & 0.650 & 0.045 & 0.09 & 2.61 & 0.01 \\
\hline Moor plantation 2 (5) & \multirow{3}{*}{ 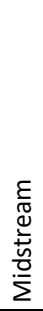 } & 0.03 & 0.01 & 0.02 & 0.03 & 0.950 & 0.060 & 0.048 & 0.14 & 2.87 & 0.04 \\
\hline Ago tailor (6) & & 0.10 & 0.03 & 0.06 & 0.04 & 0.001 & 0.020 & 0.018 & 0.15 & 2.56 & 0.05 \\
\hline Oluyole Estate 1 (7) & & 0.08 & 0.02 & 0.05 & 0.05 & 0.016 & 0.100 & 0.031 & 0.43 & 5.18 & 0.04 \\
\hline Oluyole Estate 2 (8) & \multirow{3}{*}{ 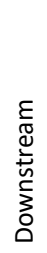 } & 0.08 & 0.03 & 0.04 & 0.04 & 0.039 & 0.080 & 0.048 & 0.28 & 3.42 & 0.06 \\
\hline Adeoyo Hospital (9) & & 0.08 & 0.03 & 0.05 & 0.04 & 0.001 & 0.080 & 0.192 & 0.07 & 1.82 & 0.04 \\
\hline Odo Ona Elewe (10) & & 0.09 & 0.03 & 0.04 & 0.05 & 0.001 & 0.100 & 0.000 & 0.11 & 0.95 & 0.08 \\
\hline Total & & 0.62 & 0.19 & 0.37 & 0.33 & 1.011 & 1.18 & 0.419 & 4.93 & 27.52 & 0.52 \\
\hline Mean & & 0.062 & 0.019 & 0.037 & 0.033 & 0.10 & 0.12 & 0.015 & 0.49 & 2.752 & 0.052 \\
\hline Standard Deviation & & 2.66 & 1.10 & 1.41 & 1.34 & 1.18 & 3.10 & 2.32 & 3.03 & 3.03 & 2.30 \\
\hline Accumulation Factor & & 2.08 & 3.00 & 1.18 & 6.50 & 18.20 & 0.47 & 3.90 & 0.16 & 0.77 & 1.14 \\
\hline CV (\%) & & 42.88 & 57.92 & 38.33 & 40.53 & 195.54 & 160.54 & 134.53 & 128.57 & 40.06 & 44.23 \\
\hline
\end{tabular}

Source: Author's Fieldwork, 2017.

The table shows that values of Lead, Cadmium and Nickel were highest at the downstream segment of the river while values of Copper and Iron were highest at the midstream segment. Manganese was however highest at the upstream segment. Out of the ten elements investigated in the study, values of Copper, Nickel, Manganese and Zinc exhibits high variability while iron exhibits relatively low variability. Values of Manganese, Nickel and Iron deviates much from mean with Nickel recording the highest standard deviation of 3.10. Accumulative Factor (AF) which gives the degree of contamination of river water at the downstream segment when compared with upstream segment revealed high values for Copper and Cobalt while the same was low for elements such as Manganese, Nickel and Iron.

\section{Spatial Variation in Concentration Level of Heavy Metals in the Study River}

Figure 3 (i-x) shows the variability in concentration levels of the ten heavy metals investigated in this study. 


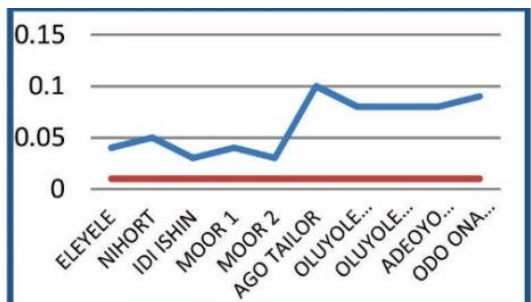

i. Lead

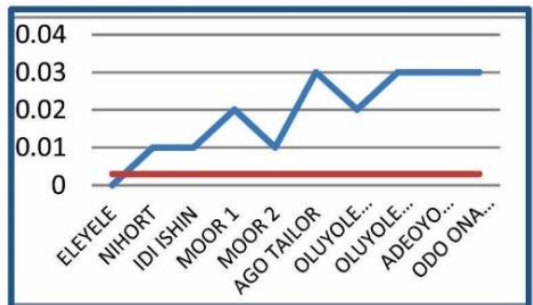

ii. Cadmium

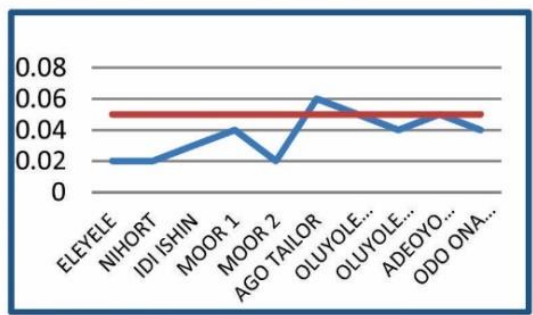

iii. Chromium

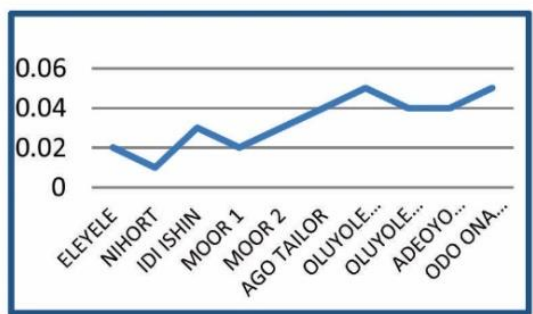

iv. Cobalt

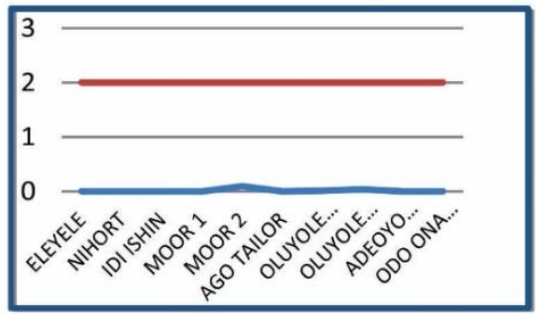

v.Copper

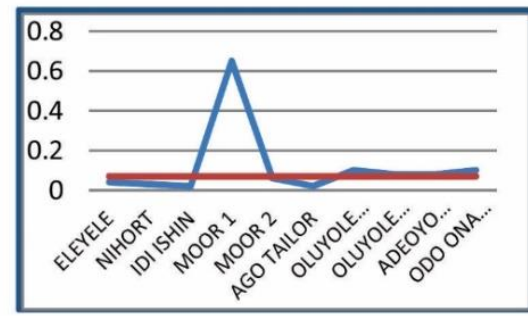

vi. Nickel

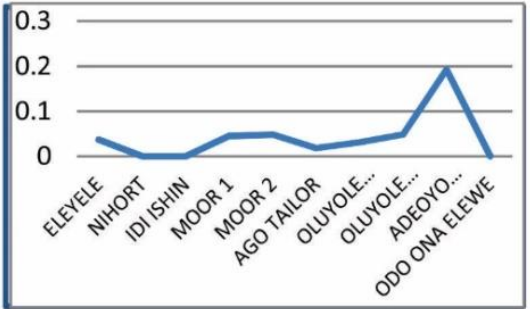

vii. Zinc

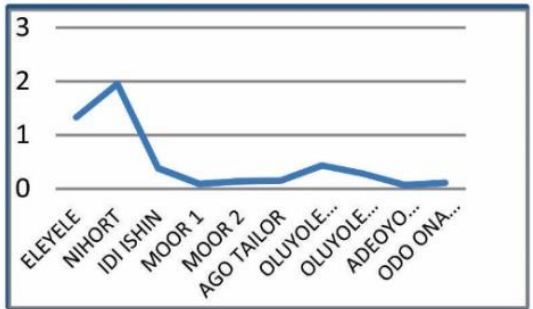

viii. Manganese

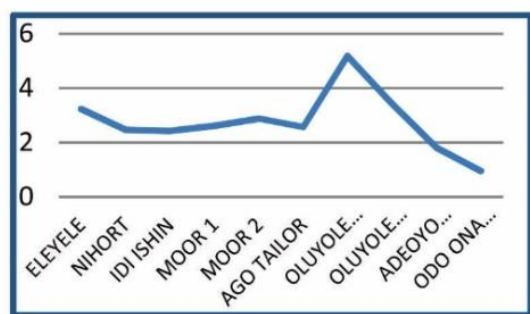

ix. Iron

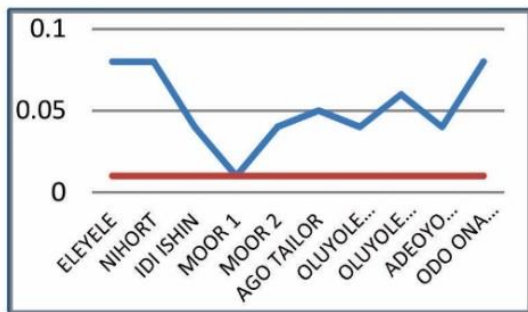

x. Arsenic

Fig 3: Spatial Variations in Concentration of Heavy Metals in River Ona Source: Author's Fieldwork 2017 
Lead concentration (Fig 3i) generally undulates around $0.4 \mathrm{mg} / \mathrm{l}$ between Eleyele and Moor Plantation II before rising to its peak value of $0.1 \mathrm{mg} / \mathrm{l}$ at Ago Tailor. The high value at Ago Tailor, however, dropped to $0.08 \mathrm{mg} / \mathrm{l}$ between Oluyole Estate and Adeoyo Hospital before slightly rising again to $0.09 \mathrm{mg} / \mathrm{l}$ at Odo ona Elewe. The significant increase in Lead value at Ago Tailor could be as a result of the presence of a mechanic workshop very close to the river. Studies such as Getachew (2015) and Ololade (2014) have indicated that the presence of mechanic workshop in an area increases heavy metal concentration as such as Lead, both in the soil and surrounding water bodies. Ololade (2014) reported that the increase in the concentration of Lead within the visibility of mechanic workshop may be linked to the presence of addictive in lubricants used by auto mechanics.

The high concentration of Lead in Oluyole Estate 1 and Oluyole Estate 2 could be attributed to the presence of industries in the area. This finding is in agreement with the earlier observation made by Ayenimo, et. al (2005) which reported that different industries contribute significantly to heavy metal load of a river. The concentration of Lead is also very high in Adeoyo Hospital. This could be as a result of effluent discharged into the river both from the hospital and from the surrounding residential areas. This factor can also be held accountable for the high concentration of Lead in Odo Ona Elewe.

Figure 3ii shows that cadmium which was absent in the study river at Eleyele gently rose from $0.01 \mathrm{mg} / \mathrm{l}$ observed at NIHORT to $0.03 \mathrm{mg} / \mathrm{l}$ at Ago Tailor. Cadmium value in the study river, however, dropped to $0.02 \mathrm{mg} / \mathrm{l}$ at Oluyole Estate I before rising back to stabilize at $0.03 \mathrm{mg} / \mathrm{l}$ in Oluyole Estate II, Adeoyo Hospital and
Odo ona Elewe. The significant increase in Cadmium value at Ago Tailor could be as a result of the presence of a mechanic workshop located very close to the river. While the high concentration in Oluyole Estate II could be as a result discharge of industrial waste into the water bodies, the high concentration in Odo Ona Elewe could be as a result of the effluents discharged into the water from anthropogenic sources. The increase in concentration of cadmium at the downstream segment level of the river can be accounted for by accumulation factor of this element in the river. Concentration of Cadmium in all the sampling points exceeded the WHO (2011) maximum permissible level for drinking water with the exception of Eleyele.

Chromium (Fig. 3iii) which was $0.02 \mathrm{mg} / \mathrm{l}$ at Eleyele rose to $0.04 \mathrm{mg} / \mathrm{l}$ at Moor Plantation I. The value of this parameter however dropped to $0.02 \mathrm{mg} / \mathrm{l}$ in Moor Plantation II before rising back to $0.06 \mathrm{mg} / \mathrm{l}$ at Ago Tailor and falling again to $0.04 \mathrm{mg} / \mathrm{l}$ at Oluyole Estate II. The increase in Chromium value at Ago Tailor could be as a result of discharge from the nearby mechanic workshop. This was observed by Ololade (2014) where Chromium was named as one of the most concentrated heavy metals in mechanic workshops. According to WHO (2011), Chromium content of surface water reflects the extent of industrial activities. This observation is particularly for Oluyole Estate I where high concentration of Chromium was observed. Concentration of Chromium in the study river is however below the WHO (2011) maximum permissible level for drinking water with the exception of that of Ago Tailor.

The value of Cobalt (Fig. 3iv) in the study river also exhibits undulating characteristics around $0.02 \mathrm{mg} / \mathrm{l}$ between Eleyele and Moor Plantation I before 
rising gently to its peak value of $0.05 \mathrm{mg} / \mathrm{l}$ at Oluyole Estate I. The high value at Oluyole Estate I however dropped to $0.04 \mathrm{mg} / \mathrm{l}$ at Oluyole Estate II and Adeoyo Hospital before slightly rising again to $0.05 \mathrm{mg} / \mathrm{l}$ at Odo Ona Elewe. The high concentration of Cobalt in Oluyole Estate could be associated with discharge of industrial effluents that are generated as a result of industrial activities in the area. The high concentration in Odo Ona Elewe could also be linked to the effluents discharged into the water that comes from anthropogenic sources. There is no WHO recommendation for Cobalt in drinking water.

The concentration of copper in the sampled water (Fig 3v) is very low. In fact this parameter is almost absent in all the sampling points with the exception of Moor Plantation II where its value rose to $0.095 \mathrm{mg} / \mathrm{l}$. The relatively high concentration of copper in Moor plantation II could be linked to the use of fertilizers and other agricultural activities that takes place in the area. Earlier research conducted by Mortvedt (1996) indicated that fertilizers contain small amounts of heavy metal contaminants. According to the research, animal manures and sewage sludge are the main organic fertilizers and the latter may contain heavy metal contaminants.

The concentration level of Nickel in the study river can generally be considered very low (Fig 3vi). The values of this parameter in the first six sampling points with exception of Moor Plantation I do not exceed the WHO (2011) recommended limit. However, this parameter undulates around the WHO (2011) recommended limit in the last four sampling points; the development which may not be unconnected with poor waste disposal methods as these areas are highly built-up with residential houses. The significant increase in Nickel value at
Moor Plantation I could also be linked to the use of fertilizers and other agricultural activities that takes place in the area. Mortvedt (1995) indicated that fertilizers contain small amounts of heavy metals. According to the research, animal manures and sewage sludge are the main organic fertilizers and the latter may contain heavy metal contaminants.

Zinc which generally fluctuates around $0.018 \mathrm{mg} / \mathrm{l}$ in the study river was completely absent in NIHORT, Idi Isin and Odo-Ona (Fig 3vii). Zinc concentration, however, rises to its peak value of $0.192 \mathrm{mg} / \mathrm{l}$ in Adeoyo Hospital. The increase in concentration level of this parameter at Adeoyo hospital could be as a result of anthropogenic waste deposited in the river. The increased concentration could also be as a result of the natural occurrence of Cadmium and Lead as these three elements are associated metals (Philips, 1976).

Though the concentration of Manganese in drinking water is not of health concern, the value of this parameter was very high within the vicinity of NIHORT where it records a value of $1.95 \mathrm{mg} / \mathrm{l}$ (Fig 3 viii). However, the value of Manganese in the study river downstream of NIHORT did not exceed $0.043 \mathrm{mg} / \mathrm{l}$ recorded in Oluyole Estate I. The high concentration of Manganese in NIHORT could be as a result of the application of Manganese sulphate in horticultural plants at NIHORT. This chemical which is applied to the horticultural plants could be washed down to the river by rainfall. According to WHO (2011), increase in concentration of Manganese could be as a result of erosion of agricultural soils in the upstream segment into water bodies and as a result of anthropogenic activities in the riparian area of the river.

Iron concentration in the study river fluctuates between $3.22 \mathrm{mg} / \mathrm{l}$ in 
Eleyele and 2.42mg/l in Ago Tailor before rising to its peak value of $5.18 \mathrm{mg} / \mathrm{l}$ at Oluyole Estate I (Fig 3 ix). This high value, however, drops sharply to $0.95 \mathrm{mg} / \mathrm{l}$ in Odo Ona Elewe. The high concentration at Oluyole Estate I and II may have been influenced by changes in redox condition as earlier observed by Kritzberg and Ekstrom (2011). This means that more anoxic water with high concentration of soluble iron II may be feeding into the river at this point.

Arsenic concentration in the study river exhibits high variability (Fig $3 \mathrm{x}$ ). This parameter exceeds the WHO (2011) recommend limit in drinking water in all the sampling points with the exception of Moor Plantation I. Arsenic concentration was exceptionally high $(0.08 \mathrm{mg} / \mathrm{l})$ in the study river at Eleyele, NIHORT and OdoOna. Its high concentration in these places may be due to the nature of underlying geology and industrial processing of paper, wood preservatives and textiles in those places.

\section{Inter-relationships of Heavy Metal in the Study River}

A multiple correlation was generated among the parameters investigated to enable an understanding of the relationships that exists between them and the type and the extent of their relationships. The varieties of these relationships are as seen in the correlation matrix (Table 2).

Table 2: Inter-relationships of Heavy Metal in the Study River

\begin{tabular}{|l|c|l|l|l|l|l|l|l|l|l|}
\hline & $\mathrm{Pb}$ & $\mathrm{Cd}$ & $\mathrm{Cr}$ & $\mathrm{Co}$ & $\mathrm{Cu}$ & $\mathrm{Ni}$ & $\mathrm{Zn}$ & $\mathrm{Mn}$ & $\mathrm{Fe}$ & $\mathrm{As}$ \\
\hline Lead & 1.00 & & & & & & & & & \\
\hline Cadmium & 0.84 & 1.00 & & & & & & & & \\
\hline Chromium & 0.81 & 0.83 & 1.00 & & & & & & & \\
\hline Cobalt & 0.73 & 0.70 & 0.70 & 1.00 & & & & & & \\
\hline Copper & -0.28 & - & -0.33 & 0.07 & 1.00 & & & & & \\
\hline Nickel & -0.22 & 0.11 & 0.12 & -0.23 & -0.14 & 1.00 & & & & \\
\hline Zinc & 0.16 & 0.32 & 0.30 & 0.17 & 0.04 & 0.07 & 1.00 & & & \\
\hline Manganese-0.32 & - & -0.61 & -0.68 & -0.24 & -0.29 & -0.32 & 1.00 & & \\
\hline Iron & -0.06 & - & 0.06 & 0.08 & 0.24 & -0.02 & -0.10 & 0.14 & 1.00 & \\
\hline Arsenic & 0.21 & - & -0.35 & -0.06 & -0.16 & -0.64 & -0.32 & 0.62 & -0.22 & 1.00 \\
& & 0.17 & & & & & & & & \\
\hline
\end{tabular}


Source: Author's Fieldwork, 2017.

The matrix revealed high correlation between lead and cadmium ( $\mathrm{r}=0.84)$, chromium $(\mathrm{r}=0.81)$, and Cobalt $(\mathrm{r}=0.73)$ and between cadmium and chromium $(r=0.83)$ and Cobalt $(r=0.70)$. This result suggests similar sources of input (anthropogenic and natural) for these heavy metals in River Ona. These type of relationships was earlier observed by Ali, et al., (2016). According to Jiang et al (2014) and Manoj et al (2012), high concentrations between specific heavy metals in water may reflect similar levels of contamination and/or release from the same sources of pollution, mutual dependence and identical behavior during their transport in the river system.

\section{RECOMMENDATIONS AND CONCLUSION}

\subsection{RECOMMENDATIONS}

Based on the findings from this investigation, the study thus put forward the following recommendations towards reducing the rate of heavy metal pollution in rivers. High level of heavy metal pollution to a large extent affects the quality of the river as well as the biota present in and around the water body.

i. Public Awareness Forums should be created by the Federal Environmental Protection Agency (FEPA) and Ministry of Water Resources to educate the populace about the increased degradation of River systems especially amongst people who live in the riparian environment of the river and the effects it could have on their health,

ii. people should be discouraged from using water collected directly from the river for domestic activities. This is important in order to prevent incidents of diseases known to be caused by ingestion of contaminated water,

iii. there should be proper monitoring of effluents into river bodies as an integral part of water management in the early river system. This will enable the verification of whether or not imposed standards and regulations are met. A regular schedule for sampling the river should be established on the basis of the potential pollution effect of stream water, frequency of the sampling should take into consideration the types of hazards, seasonal flows, storms and other factors which may change during the year and after the data might have been collected, and

iv. subsidies can be given to industries to enable them to treat their effluents before discharging them into the watercourses. The subsidies may come to inform of tax credits, loan with low interest or an outright grant.

\subsection{CONCLUSION}

The presence of heavy metals in an environment is one of the major concerns of pollution control and environmental agencies in most parts of the world. This is mainly due to the health implications of these metals in water as they are nonessential metals and of no benefit to humans. Although the levels of six (Lead, Cobalt, Copper, Zinc, Manganese and 
Iron) out of the ten heavy metals examined in this investigation do not exceed the safe levels for human consumption as recommended by WHO (2011), the exceedence of four of the heavy metals (Cadmium, Chromium, Nickel and Asenic) above the WHO (2011) recommended levels and constant presence of heavy metals in concentration near those limits considered safe for human consumption, is a reason for concerned, and residents who constantly consume fish from river Ona should be warned.

Heavy metal pollution can be controlled by practicing low-impact development activities, improved chemical handling (e.g. management of motor fuels and oil and lubricants, fertilizer and pesticides). Industries operating within the drainage basin should be mandated to treat their effluents before discharging them into rivers. The system of sewage disposal which has its terminal at a waste treatment plants should also be encouraged by government agencies responsible.

\section{REFERENCES}

Adebola, K. D. (2001). Groundwater Quality in Ilorin Township: An Environmental Review, African Journal of Environmental Studies. 2 (2): 4-15.

Ajayi, O.; Agboola, S.B.; Olokesusi; B.F.; Wahab, B; Taiwo, O.I; Gbadegesin, M; Taiwo, D.O; Kolawole, O; Muili, A; Adeola, M.A; Olutade, O.G; Shiji, F; and Abiola M.A (2012) Flood Management in an Urban Setting: A Case Study of Ibadan Metropolis Hydrology for Disaster Management Special Publication of the Nigerian Association of Hydrological Sciences 17pp.

Alayande W. A., Mohammed G., Caleb I. and Deimodei M. I (2012) Assessment of
Urban Flood Disaster: A Case Study of 2011 Ibadan Floods. Special Publication of the Nigerian Association of Hydrological Sciences

Ali, M.M., Ali, M.C Islam, S. and Rahman, Z. (2016) Preliminary Assessment of Heavy Metals in Water and Sediment of Karnaphuli River, Bangladesh. Journal of Environmental Nanotechnology, Monitoring and Management 5:27-35.

American Public Health Association APHA (2005) Standard Methods for Examination of Water and Waste Water 4th Edition American Public Health Association, Washington, D.C.

Ayenimo, J.G.; Adeyinwo, C.E.; Amoo, I.A.; Odukudu, F.1. (2005). A Preliminary Investigation of Heavy Metals in Periwinkles from Warri River, Nigeria. J. App. Sci. 5(5): 813 - 815.

Ayoade J.O. (1988): Tropical Hydrology and Water Resources. Macmillan, London,275pp.

Biney, C. H., Amuzu, A. T, Calamari D. (1991): "A Review of Heavy Metals in the African Aquatic Environment" Annex IV; A Report of the 3rd Session of the Working Party on Pollution and Fisheries. Food \& Agricultural Organization (FAO) Corporate Document Repository.

Dadzie, E.S (2012) Assessment of Heavy Metal Body Contamination of Densu River, Weija from Leachate Unpublished B.Sc Project Kwame Nkrumah University of Science and Technology Ghana, 61pp.

Egbinola, C.N; Amanambu, C; and Amobichukwu, A. (2013) Climate Variation Assesment Based on Rainfall and Temperature in Ibadan, South- 
Western Nigeria Journal of Environment and Earth Science 3 (11): 32-47.

Fabiyi, O. O. (2006). Urban Land Use Change Analysis of a Traditional City from Remote Sensing Data: The Case of Ibadan Metropolitan Area, Nigeria. Rex Charles Publishers, Nigeria.

Getachew (2015): Analyzing soil contamination Status in Garage and Auto Mechanical Workshops of Shashemane City: Implication for Hazardous Waste Management; Environ Syst Res 4:15.

Greaney, K.M (2005) An Assessment of Heavy Metal Contamination in the Marine Sediments of Las Perlas Archipelago, Gulf of Panema. Unpublished M.Sc Dissertation Heriot-Watt University, Edinburg 114pp.

Iroye, K.A. (2017): Correlating Pattern of River Discharge with Degree of Urbanization in Sub-catchment of River Asa in Ilorin, Nigeria. Ethiopian Journal of Environmental Studies and Management, 10 (2): 251-261.

Islam, M.S; Ahmed, M.K; Habibullah-AlMamun, M and Hoque, M.F (2015) Preliminary Assessment of Heavy Metal Contamination in Surface Sediment from a River in Bangladesh Environ, Earth, Science 73: 1837-1848

Jiang, X., Teng, A. Xu, W., liu, X., (2014) Distribution and Pollution Assessment of Heavy Metals in Surface Sediments in the yellow Sea. Mar. Pollut.Bull., http://dx.doi.org/10.1016/j.marpolbul on 20th March, 2014.

Kritzberg, E.S. and Ekstrom, S.M. (2011) Increasing Iron Concentrations in Surface Water: A Factor Behind Brownification? Biogeosciences Discuss 9. Published by
Gorpernicus Publication on Behalf of the European Geoscience Union 1465-1478.

Manoj, K., B. Kumar and P.K. Padhy, (2012) Characterization of Metals in Water and Sediments of Subarnarekha River Along the Projects' Sites in Lower Basin, India. Universal J. Environ. Res. Technol., 2: 402-410.

Martin, J.A.R; Arana; C.D., RamosMiras, J.J, Gil, C, and Boluda R. (2015) Impact of 70 Years Urban Growth Associated with Heavy Metal Pollution. Environmental Pollution 196:288-302.

Milicevic, D. (2013) Data Acquisition: Definition of Basic Data Set for Water Quality Assessment Accessed at http://www.dundjer.co.rs/cpe/arwgm/da taacquisition.htm\#ftn/ on 15th Nov. 2013.

Mortvedt (1996) Heavy Metal Contaminants in Inorganic Fertilizers. Fertilizer Research, 43:55-61.

National Population Commission NPC (2006) Nigeria Pollution Census

Ololade I.O. (2014) An Assessment of Heavy-Metal Contamination in Soils within Auto-Mechanic Workshops Using Enrichment and Contamination Factors with Geoaccumulation Indexes. Journal of Environmental Protection 5: 970-982.

Philips, D.J.H (1976) The Common Mussel Mytilus Edulis as an Indicator, of Pollution by Zinc, Cadmium, lead and Copper: Relationships of Metals in the Mussel to those Discharged by Industry Marine Biology 39 (1): 77-80.

Tam, N.F.Y., Wong,Y.S. (2000) Spatial Variation of Heavy Metals in Surface Sediments of Hong Kong Mangrove 
Swamps. Environmental Pollution 1(10):195-205.

UNICEF (2016) Water Collection: A Colossal Waste of Time for Women and Girls Press Release Available at https://www.unicef.org/media/media_92 690.html Accessed on 18th June, 2016.

Wangboje O.M and Ekundayo O.T (2013). Metals Concentrations in Surface Water of Ikpoba Reservoir, Benin City, Nigeria. Nigeria J. Technol. 32 (11): 6166.

World Health Organization WHO (2011). Guidelines for Drinking Water Quality. 5th Ed. Geneva. 13pp. 